\title{
Growth Hormone Enhances Hepatic Epidermal Growth Factor Receptor Concentration in Mice
}

\author{
John-Olov Jansson, ${ }^{\star \star}$ Staffan Ekberg, ${ }^{\ddagger}$ Steven B. Hoath, Wesley G. Beamer," and Lawrence A. Frohman* \\ Divisions of ${ }^{*}$ Endocrinology and ${ }^{\S}$ Neonatology, University of Cincinnati College of Medicine, Cincinnati, Ohio 45267; \\ "Jackson Laboratory, Bar Harbor, Maine 04609; and ${ }^{\ddagger}$ Department of Physiology, University of Goteborg, Sweden
}

\begin{abstract}
The effect of growth hormone (GH) on binding of epidermal growth factor (EGF) to liver membrane preparations was investigated in hypophysectomized mice and partially GH-deficient, genetic mutant "little" (lit/lit) mice. The EGF binding of normal male mice and testosterone-treated females was higher than in normal females. Due to diminished receptor concentration, hepatic EGF binding was decreased in male and female lit/lit mice to a level that was unaffected by gender or androgen treatment. GH replacement therapy by intermittent injections and continuous infusion restored the EGF binding of hypophysectomized mice to normal male and female levels, respectively, suggesting a role for the more pulsatile GH secretion in normal males. In lit/lit mice, however, both continuous and intermittent $\mathbf{G H}$ resulted in EGF binding levels comparable to those in normal females. In normal males continuous GH suppressed EGF binding. In conclusion, endogenous GH secretion induces EGF receptors in mice and this effect may be modulated by sex differences in GH secretion.
\end{abstract}

\section{Introduction}

Epidermal growth factor (EGF) ${ }^{1}$ is a polypeptide originally isolated from the mouse submaxillary gland (1). Subsequent studies have shown that EGF exerts a potent mitogenic action, but also modulates several other biological functions that are initiated by binding of EGF to a membrane-associated protein receptor $(2,3)$. The results of recent studies indicate that the concentration of EGF receptors markedly affects growth properties at least in tumor cells $(4,5)$. Thus, knowledge concerning the regulation of EGF receptors is essential for understanding the effects of EGF. There is, however, limited information about the possible role of EGF in physiological processes during adult life and about possible interactions between EGF and hormones involved in promoting growth. Growth hormone (GH), the major stimulator of postnatal growth, acts at least in part by stimulating production of insulin-like growth factor-I

This work was presented in part at the 69th Annual Meeting of the Endocrine Society, Indianapolis, IN, June 1987.

Address reprint requests to Dr. Lawrence A. Frohman, Division of Endocrinology and Metabolism, ML 547, University of Cincinnati College of Medicine, Cincinnati, OH 45267.

Received for publication 17 November 1987 and in revised form 7 June 1988.

1. Abbreviations used in this paper: EGF, epidermal growth factor; $\mathrm{GH}$, growth hormone; IGF-I, insulin-like growth factor-I.

J. Clin. Invest.

(C) The American Society for Clinical Investigation, Inc.

0021-9738/88/12/1871/06 \$2.00

Volume 82, December 1988, 1871-1876
(IGF-I), which may function in a paracrine and autocrine as well as endocrine manner (6-8). At present there is little information about GH interaction with other locally produced growth factors such as EGF.

Measurement of GH in repeated blood samples from cannulated undisturbed rats has convincingly demonstrated that, although mean plasma $\mathrm{GH}$ levels are similar in males and females, the GH secretory pattern is sex differentiated. Male rats, as well as androgen-treated females, display large $\mathrm{GH}$ pulses at 3-3.3-h intervals interrupted by low baseline secretion while normal females have smaller and more frequent pulses and higher baseline levels, i.e., more continuous GH secretion (9-11). Although comparable cannulation studies in mice are unavailable, measurement of plasma GH levels in single blood samples from large groups of animals are consistent with a more continuous and less variable $\mathrm{GH}$ secretion in females, i.e., sex-related differences similar to those in rats (12). A pulsatile plasma GH pattern has been shown to be more effective than a continuous one in promoting body growth $(10,13,14)$, and the GH secretory pattern has also been implicated in the regulation of several sex-differentiated hepatic functions $(10,15)$.

It has recently been reported that hepatic EGF receptor concentrations in male rodents can be increased by testosterone $(16,17)$, raising the possibility that androgen-induced changes in the pattern of $\mathrm{GH}$ secretion exert a mediating role. In the present study we investigated the effect of $\mathrm{GH}$ on hepatic EGF binding in two models of isolated GH deficiency. Homozygous "little" (18) mice carry a recessive single gene mutation, designated lit, that affects the receptor for GH-releasing factor (19). Although the lit/lit mouse, unlike other GH-deficient dwarf mouse strains and hypophysectomized animals, does not exhibit other pituitary hormone deficiencies $(20,21)$, it is at present uncertain that the mutation affects only GH secretion. Therefore, studies were also performed in hypophysectomized mice given thyroxine, glucocorticoids, and testosterone as replacement therapy. To elucidate the possible role of the plasma GH pattern in determining the sex differentiation of hepatic EGF receptors, the effects of continuous and intermittent $\mathrm{GH}$ treatment were compared.

\section{Methods}

Animals and experimental protocols. Mature normal $(+/ l i t)$ and mutant (lit/lit) C57BL/6J mice were bred at Jackson Laboratory (Bar Harbor, ME). Heterozygous $(+/$ lit) mice have been reported to be phenotypically identical to wild type $(+/+)$ mice $(18)$. Normal $(+/+)$ C57BL/6 mice from Harlan Laboratories (Madison, WI) were hypophysectomized by Dr. Les Barnes, Altech Laboratory (Madison, WI) 2 d before initiation of hormone treatment. Completeness of hypophysectomy was verified at autopsy by inspection of the sella. All mice were fed standard Purina rat chow and water ad lib. 
Human (BV-NPA-13) and bovine (NIH-GH-B18) GH were provided through the National Hormone and Pituitary Program (Baltimore, MD). Continuous infusions of these hormones were accomplished using osmotic minipumps (model 2001, Alza Corp., Palo Alto, CA) implanted subcutaneously under ether anesthesia on the backs of the animals. The filling volume of these pumps is $225 \mu$ l and the pumping rate at $37^{\circ} \mathrm{C}$ is $1 \mu \mathrm{l} / \mathrm{h}$. Osmotic minipumps filled with vehicle only were implanted in some of the control animals without any effect on EGF binding as compared with untreated animals. Human GH (1 $\mathrm{mg} / \mathrm{kg}$ per d) was given intermittently as subcutaneous injections at 12 -h intervals at 800 and $2,000 \mathrm{~h}$. The last injection was given $12 \mathrm{~h}$ before the animals were killed. Cortisone acetate $(500 \mu \mathrm{g} / \mathrm{kg}$ per d) and L-thyroxine $(10 \mu \mathrm{g} / \mathrm{kg}$ per d) were given to hypophysectomized mice in daily subcutaneous injections at $800 \mathrm{~h}$. The hormone treatment continued for 5-7 d.

Female mice and hypophysectomized male mice were injected subcutaneously with testosterone enanthate $(15 \mathrm{mg} / \mathrm{kg})$ in $0.2 \mathrm{ml}$ sesame oil 10 and $7 \mathrm{~d}$, respectively, before measurement of hepatic EGF binding. Controls received vehicle only.

Hepatic membrane preparation. Immediately after decapitation of the animals, liver membranes were prepared by a modification of previously described methods $(22,23)$. In brief, liver parenchymal tissue (usually $1 \mathrm{~g}$ ) kept in ice-cold buffer $(250 \mathrm{mM}$ sucrose, $25 \mathrm{mM}$ Tris- $\mathrm{HCl}, \mathrm{pH}$ 7.4) was dissected free of connective tissue and larger vessels, finely minced, and washed. The tissue was then diluted to $5 \mathrm{vol}$ of buffer and homogenized with a polytron (Brinkmann Instruments, Inc., Westbury, NY) at setting 7 for $90 \mathrm{~s}$. The crude homogenate was filtered through two layers of cheesecloth and centrifuged at $600 \mathrm{~g}$ for $10 \mathrm{~min}$. The supernatant containing the membrane fraction was then centrifuged at $10,000 \mathrm{~g}$. The resulting supernatant was adjusted to 0.1 $\mathrm{M} \mathrm{NaCl}$ and $0.2 \mathrm{mM} \mathrm{MgSO}_{4}$ and recentrifuged at $48,000 \mathrm{~g}$ for $40 \mathrm{~min}$. The pellet was washed by resuspension in $50 \mathrm{mM}$ Tris- $\mathrm{HCl}(\mathrm{pH} \mathrm{7.6)}$ and centrifuged at $48,000 \mathrm{~g}$ for $30 \mathrm{~min}$. All procedures were performed at $4^{\circ} \mathrm{C}$. The pellet was then diluted in $50 \mathrm{mM}$ Tris- $\mathrm{HCl}$ and stored in aliquots at $-20^{\circ} \mathrm{C}$. The protein content of the membranes was determined (24) using BSA as standard.

Receptor assay. EGF was prepared from male mouse submaxillary glands by the method of Savage et al. (25). Radioiodination of EGF was performed using chloramine-T. The reaction was carried out for $40 \mathrm{~s}$ in total volume of $100 \mu \mathrm{l}$ and was stopped by addition of 2-mercaptoethanol. ${ }^{125} \mathrm{I}-\mathrm{EGF}$ was purified on a disposable $\mathrm{C}_{18}$ SepPak cartridge (Waters Associates, Milford, MA) by elution with 35\% acetonitrile/65\% acidified water ( $\mathrm{pH} 2.1$ ). After evaporation of the acetonitrile under an $\mathrm{N}_{2}$ stream, the EGF solution was adjusted to $\mathrm{pH} 4.5$ with $\mathrm{NaOH}$ and purified further on a Sephadex G-25 column (Pharmacia LKB Biotechnology, Piscataway, NJ). The column was washed with $100 \mathrm{mM}$ ammonium acetate containing $2.5 \% \mathrm{BSA}$ and equilibrated with acidified water ( $\mathrm{pH} 2.1$ ) before the EGF-containing solution was applied. The peptide was eluted in $100 \mathrm{mM}$ ammonium acetate with $2.5 \% \mathrm{BSA}$ and stored at $-20^{\circ} \mathrm{C}$.

EGF binding was performed by a modification of the method of Hock and Hollenberg (23). Liver membranes and 0.5-0.8 ng (150,000-250,000 cpm, 0.3-0.5 nM final concentration) ${ }^{125} \mathrm{I}-\mathrm{EGF}$ were incubated at room temperature in the presence or absence of excess $(2.5 \mu \mathrm{g})$ unlabeled EGF. Under these conditions there was a linear relation between the quantity of mouse liver membranes (12.5$200 \mu \mathrm{g}$ protein) and the specific binding of labeled EGF. In subsequent experiments $125 \mu \mathrm{g}$ of membrane protein was used per tube. In displacement experiments 0-100 $\mathrm{ng}(0-66 \mathrm{nM})$ unlabeled EGF was added to the incubation tubes. The specific activity of the labeled EGF (175-225 $\mu \mathrm{Ci} / \mu \mathrm{g})$ was assessed by comparing the effects of increasing concentrations of labeled and unlabeled EGF on relative ligand binding to placental membranes $(23,26)$.

The binding reaction was performed in a total volume of $0.25 \mathrm{ml}$ buffer $(0.25 \%$ BSA in $50 \mathrm{mM}$ PBS, pH 7.3) in $12 \times 75-\mathrm{mm}$ plastic tubes. The reaction was terminated by addition of $4 \mathrm{ml}$ ice-cold buffer followed by immediate separation of bound and free ${ }^{125}$ I-EGF by filtration through GF/B filters (Whatman Chemical Separation, Inc.,
Clifton, NJ) using a multiple manifold apparatus (Millipore/Continental Water Systems, Bedford, MA). The filters were washed twice with 4 $\mathrm{ml}$ buffer. The radioactivity of the filters was counted in a gammaspectrometer with an efficiency of $70 \%$. Specific binding was measured as the difference between total (in the absence of unlabeled EGF) and nonspecific (in the presence of excess unlabeled EGF) binding of ${ }^{125} \mathrm{I}$ EGF. Nonspecific binding was always $2 \%$ or less of total added radioactivity. The time course of specific binding of ${ }^{125}$ I-EGF to liver membranes is shown in Fig. 1. Maximal specific binding was reached after $\sim 30-45 \mathrm{~min}$ and then remained relatively constant, as previously reported $(23,27)$. In subsequent studies incubation was always performed for $60 \mathrm{~min}$ at room temperature. In separate experiments the possible degradation of iodinated EGF during these conditions was investigated. After a standard assay incubation, the membranes were centrifuged and the supernatant was aspirated. More than $90 \%$ of the tracer in the supernatant could be precipitated by $10 \%$ TCA. Moreover, the binding of tracer to fresh liver membranes was reduced by $<10 \%$ after preincubation at standard assay conditions, in line with the results of a previous study in which a slightly different protocol was used (26).

Data analysis. EGF receptor concentrations and binding dissociation constants were calculated according to the method of Scatchard (28), using data obtained from displacement experiments in which varying concentrations (0-66 $\mathrm{nM}$ ) of unlabeled EGF were added to 0.3 nM of labeled EGF. The total concentration of bound EGF (labeled and unlabeled) was calculated assuming a similar relative specific binding of unlabeled and labeled EGF. The ratio of bound/free EGF was then plotted as a function of bound EGF, and the slope and the intercept with the $x$-axis were calculated by standard linear regression. Comparisons were made by $t$ test, or, when more than two groups were compared, by one way analysis of variance followed by Student-Newman-Keul's multiple range test among different groups (29). Data are presented as mean \pm SE. $P$ values $<0.05$ were considered significant.

\section{Results}

The results of preliminary studies indicated that the specific binding of EGF to hepatic membranes from $\mathrm{GH}$ deficient lit/lit male mice (3.9 $\pm 1.3 \%$ total added radioactivity; $n=3$ ) was markedly lower than to membranes of heterozygous $+/$ lit male mice $(24.0 \pm 2.8 \% ; n=3, P<0.001)$. A fixed concentration of labeled EGF and varying concentrations of unlabeled EGF were incubated with $+/$ lit and lit/lit liver membranes. The total specific EGF binding as a function of total concentration of added peptide is shown in Fig. 2. EGF binding to $+/$ lit as well as lit/lit (see inset) liver membranes was saturable. Scatchard analyses of both $+/$ lit and lit/lit binding curves were consistent with a single class of binding sites. The results of Scatchard analysis of the experiment shown in Fig. 2 and of two other binding studies are summarized in Table I. These data confirm that the EGF receptor concentration $\left(B_{\max }\right)$ is $\sim 12$ times greater in $+/$ lit than in lit/lit membranes. Although the $K_{d}$ was higher in $+/$ lit animals, this difference was not statistically significant.

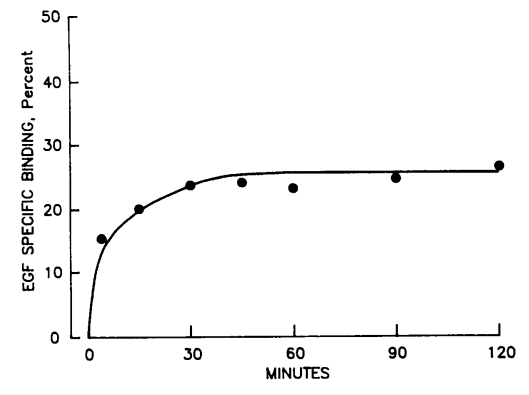

Figure 1. Time course of specific binding of ${ }^{125}$ I-EGF to hepatic membranes. Binding is expressed as \% of total added radioactivity $(250,000 \mathrm{cpm})$ bound to $125 \mu \mathrm{g}$ of liver membrane protein from nor$\mathrm{mal}(+/+)$ C57BL/6J male mice. 


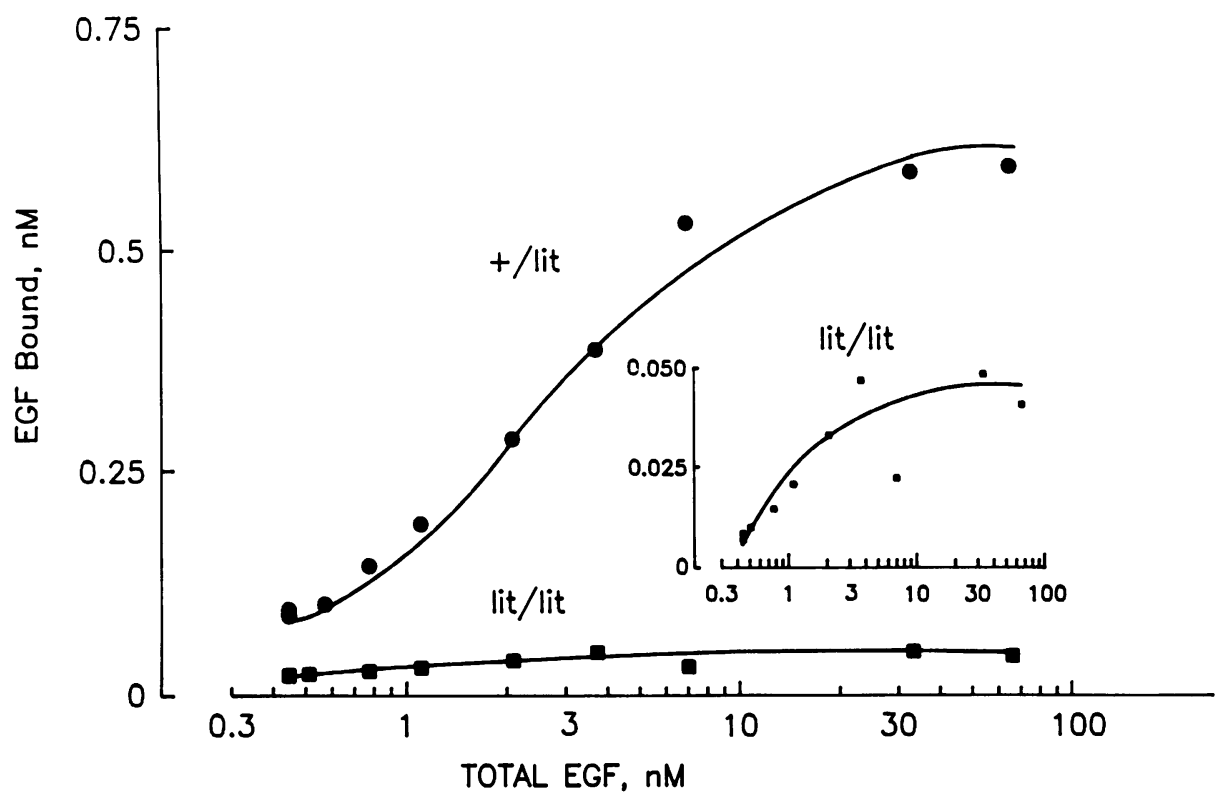

Figure 2. Saturation analysis of EGF binding to liver membranes of $+/$ lit and lit/lit male mice. Specifically bound EGF is plotted as a function of total EGF concentration. A membrane suspension (125 $\mu \mathrm{g}$ protein) and a fixed concentration of ${ }^{125}$ I-EGF $(0.3 \mathrm{nM})$ were incubated with varying concentrations of unlabeled EGF (0-64 nM) at $24^{\circ} \mathrm{C}$ for $60 \mathrm{~min}$. Curves were calculated. Inset, magnification of the EGF binding curve for lit/lit mice. The mean $K_{\mathrm{d}}$ and $B_{\max }$ values for this and two other experiments as calculated according to Scatchard are shown in Table I.
The influence of the lit mutation on hepatic EGF binding of female mice was next investigated. The specific EGF binding to liver membranes of normal $(+/$ lit $)$ female mice was about one-third that of normal $(+/$ lit $)$ males, as shown in Fig. 3. EGF binding to membrane preparations of lit/lit animals of both sexes was even lower than that of normal females. In addition, there was no sex difference in EGF binding in lit/lit mice.

The effect of testosterone was next compared in normal $(+/$ lit $)$ and lit/lit female mice. Testosterone administration to normal mice produced a threefold increase in hepatic EGF binding (Fig. 4). In contrast, testosterone had no effect on EGF binding in lit/lit female mice. EGF binding was significantly lower in vehicle-treated lit/lit female mice as compared with vehicle-treated +/lit females, confirming the results in Fig. 3 .

The effects of continuous and intermittent (two subcutaneous injections per day) treatment with human $\mathrm{GH}$ on hepatic EGF binding were compared in male and female lit/lit mice. As shown in Fig. 5, there was no difference between the effects of these two treatment protocols in either males or females. Both continuous and intermittent GH treatment restored EGF binding to a level comparable to that in $+/$ lit female mice (Fig. 5 , bottom), but significantly lower than that in $+/$ lit male mice (Fig. 5, top).

The effects of continuous subcutaneous infusions of human and bovine GH were compared in a separate experiment. Specific hepatic EGF binding in lit/lit male mice treated with human $(13.2 \pm 1.5 \% ; n=5)$ and bovine $(11.0 \pm 2.3 \%$;

Table I. Characteristics of ${ }^{125}$ I-EGF Binding (mean $\pm S E$ ) to Hepatic Membranes of Adult Male Mice

\begin{tabular}{ccc}
\hline Genotype & Binding capacity $\left(B_{\max }\right)$ & $K_{\mathrm{d}}$ \\
\hline & fmol/mg protein & $n M$ \\
$+/ l i t$ & $1,249 \pm 304$ & $2.21 \pm 0.62$ \\
lit/lit & $101 \pm 20^{*}$ & $1.00 \pm 0.22$
\end{tabular}

Data are pooled from three separate experiments.

$* P<0.01$ vs. $+/$ lit $n=4) \mathrm{GH}$ were similar, although the binding of both groups was significantly greater $(P<0.01)$ than in vehicle-treated lit/lit males $(4.4 \pm 0.8 \% ; n=7)$.

The effects of continuous and intermittent $\mathrm{GH}$ treatment on hepatic EGF binding were compared in another model of isolated GH deficiency: hypophysectomized, +/+ C57BL/6 male mice given thyroxine, glucocorticoid, and androgen replacement therapy. As shown in Table II, the hepatic EGF binding in hypophysectomized $+/+$ male mice was of the same magnitude as that in lit/lit male mice (Fig. 5). Moreover, EGF binding in hypophysectomized mice was markedly lower than in sham operated males. In contrast to the results in lit/lit mice (Fig. 5), intermittent GH treatment by two daily subcutaneous injections in hypophysectomized $+/+$ male mice completely restored EGF binding to levels observed in normal $+/+$ males while continuous $\mathrm{GH}$ treatment was less effective (Table II).

The effect of eliminating the pulsatile pattern of plasma $\mathrm{GH}$ in $+/+$ mice was determined by continuously infusing human GH using osmotic minipumps. This treatment resulted in a significant decrease of hepatic EGF binding in $+/+$ male mice (Table III), in striking contrast to the results in lit/lit male mice (Fig. 5).

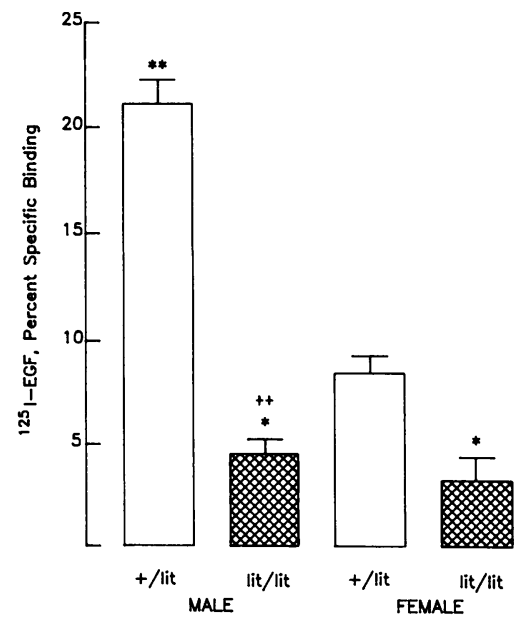

Figure 3. Specific EGF binding (mean $\pm \mathrm{SE}$ ) to liver cell membranes from $+/$ lit and lit/lit male and female mice. Each group contained five to seven animals. * **, $P<0.05, P<0.01$ vs. + /lit female mice; ,$++ P<0.01$ vs. $+/$ lit male mice. 


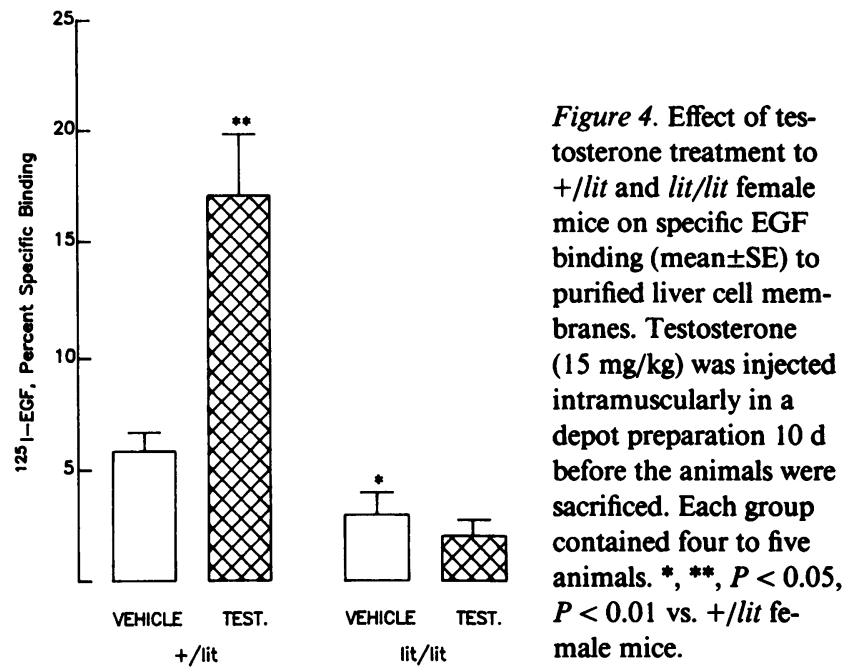

\section{Discussion}

The present results clearly demonstrate that the hepatic EGF binding, which is greater than in many other organs (2), is to a large part dependent on endogenous GH. EGF binding to isolated hepatic membranes from hypophysectomized male mice given replacement therapy with thyroxine, glucocorticoids, and testosterone was much lower than to membranes from sham-operated mice. There was also a marked decrease in hepatic EGF binding in lit/lit mice that exhibit an isolated GH deficiency $(18,20)$. In addition, $\mathrm{GH}$ treatment increased hepatic EGF binding in both hypophysectomized and lit/lit mice. Scatchard analysis of the binding data suggests that the reduction in EGF binding to membranes of GH-deficient mice is due to a decrease in concentration rather than a change in affinity of EGF receptors. The decreased EGF receptor con-
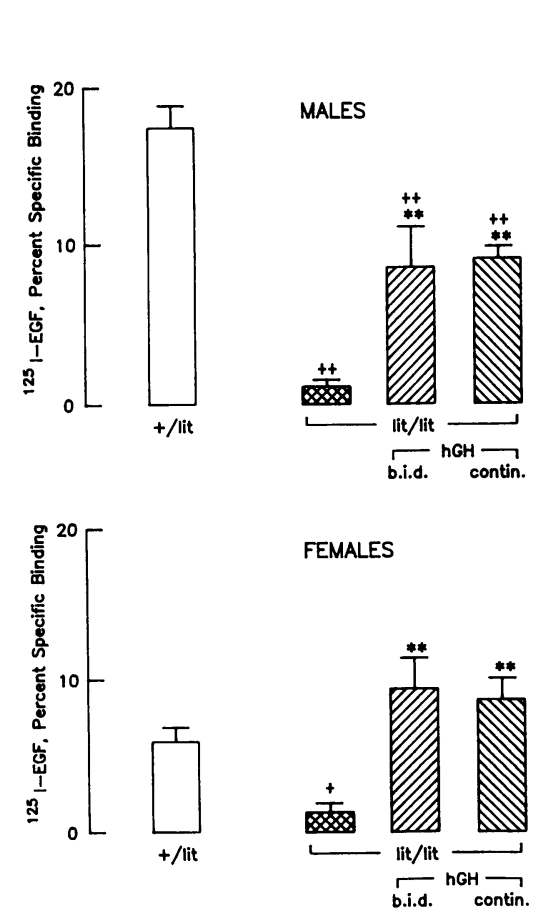

Figure 5. Specific EGF binding (mean $\pm \mathrm{SE}$ ) to liver cell membranes from +/lit mice, untreated lit/lit mice, and lit/lit mice treated intermittently or continuously with human $\mathrm{GH}$ for $7 \mathrm{~d}$. The animals were given $1,000 \mu \mathrm{g} / \mathrm{kg}$ per $d$ either in two daily subcutaneous injections $(500 \mu \mathrm{g} / \mathrm{kg})$ at 12 -h intervals or as a continuous subcutaneous infusion using osmotic minipumps. The experiment was performed in male (top) and female (bottom) mice and there were three to five animals per group.,,$+++ P$ $<0.05, P<0.01$ vs. $+/$ lit mice; $* *, P<0.01$
Table II. Specific EGF Binding to Hepatic Membranes from Sham-operated Male Mice, from Thyroxine-, Cortisone-, and Testosterone-treated Hypophysectomized Male Mice, and from Hypophysectomized +/+ Male Mice Also Given Intermittent or Continuous Treatment with Human GH for $7 d$

\begin{tabular}{lc}
\hline \multicolumn{1}{c}{ Experimental group } & ${ }^{125}$ I-EGF specific binding \\
\hline \multirow{2}{*}{ Sham } & $\%$ \\
& 17.3 \\
Hypophysectomy & 20.4 \\
& 2.2 \\
Hypophysectomy + hGH $500 \mu \mathrm{g} / \mathrm{kg} \times 2$ & 1.4 \\
& 19.3 \\
Hypophysectomy $+\mathrm{hGH} 1,000 \mu \mathrm{g} / \mathrm{kg}$ per $24 \mathrm{~h}$ & 20.1 \\
continuously & 12.2 \\
& 9.8 \\
\hline
\end{tabular}

The animals were given $\mathrm{hGH}, 1,000 \mu \mathrm{g} / \mathrm{kg}$ per $\mathrm{d}$, either in two daily subcutaneous injections $(500 \mu \mathrm{g} / \mathrm{kg} \mathrm{hGH})$ at $12-\mathrm{h}$ intervals or as a continuous subcutaneous infusion (1,000 $\mu \mathrm{g} / \mathrm{kg}$ per $24 \mathrm{~h}$ ) using osmotic minipumps. All hypophysectomized animals were also given replacement therapy with thyroxine, cortisone acetate, and testosterone. Values from individual animals are presented.

centration in GH-deficient lit/lit mice does not, however, represent a generalized phenomenon, since levels of $\mathrm{GH}$ and prolactin receptors are normal in lit/lit male mice $(30,31)$. Although human GH binds to both growth-promoting and lactogenic receptors of rodent liver (30), its stimulatory effect on EGF binding is exerted only through growth-promoting receptors, since bovine $\mathrm{GH}$, which does not have lactogenic properties, was as potent as human $\mathrm{GH}$. The present results do not exclude the possibility that the changes in EGF binding are secondary to alterations in EGF levels (3). However, we have not observed any effects of GH on EGF levels, as measured by RIA, in mouse submaxillary glands or urine (unpublished observations).

In the present study hepatic EGF binding was significantly greater in normal male than female mice, confirming previous reports $(16,17)$. Our data are also consistent with the hypothesis that the sex difference in hepatic EGF binding is related to the pattern of GH secretion. In addition to the marked decrease in EGF binding in both male and female lit/lit mice, the levels did not differ between the sexes, even though the secretion of other pituitary-dependent hormones, including sex ste-

Table III. Effect of Continuous Subcutaneous Infusion of Human GH (1,000 $\mathrm{gg} / \mathrm{kg}$ per $24 \mathrm{~h})$ for $7 \mathrm{~d}$ to Normal + ++ Male Mice on Specific ${ }^{125}$ I-EGF Binding (Mean $\pm S E$ ) to Purified Hepatic Membranes

\begin{tabular}{|c|c|c|}
\hline Experimental group & $n$ & ${ }^{125}$ I-EGF specific binding \\
\hline & & $\%$ \\
\hline$+/+$ male mice & 4 & $31.0 \pm 2.1$ \\
\hline$+/+$ male mice $+\mathrm{hGH}$ continuously & 5 & $20.2 \pm 1.1^{*}$ \\
\hline
\end{tabular}


roids, is not decreased in lit/lit mice $(20,21)$. Moreover, androgen treatment stimulated hepatic EGF binding in normal female mice but not in lit/lit females, indicating that the absence of sex differences in EGF binding of lit/lit mice is not caused by androgen deficiency but is best explained by a regulatory role of $\mathrm{GH}$ secretion in normal mice.

There is considerable evidence for androgen-dependent sex differentiation of $\mathrm{GH}$ secretion in the rat $(10,11)$ and probably also the mouse (12). GH secretion in normal males and androgen-treated females is characterized by episodic pulses every $3.3 \mathrm{~h}$, whereas untreated females exhibit a more continuous pattern of $\mathrm{GH}$ secretion. The assumption that the plasma GH pattern is a determinant of hepatic EGF binding is supported by the present findings that intermittent administration of GH in a physiological replacement dose (13) at 12-h intervals to hypophysectomized mice restored EGF binding to levels of normal male mice. Continuous infusion of the same quantity of GH increased EGF binding only to values seen in normal females. We have also obtained in hypophysectomized rats results (not shown) similar to those in hypophysectomized mice.

Intermittent administration of $\mathrm{GH}$ at the physiological replacement dose that completely masculinized EGF binding in hypophysectomized $+/+$ mice enhanced hepatic EGF binding in lit/lit mice only to a level seen in normal female mice. Previous studies suggest that much larger doses of $\mathrm{GH}$ are necessary to masculinize various sex-differentiated hepatic functions in lit/lit mice as compared with hypophysectomized rats (31-34). Therefore, factors other than $\mathrm{GH}$ appear to influence hepatic EGF receptors in these animals. Although the only known defect in lit/lit mice is an isolated GH deficiency due to a defective GH-releasing factor receptor $(19,20)$, it is possible that the lit mutation also directly affects genes related to GH sensitivity. Alternatively, the continuous presence of low but measurable levels of endogenous $\mathrm{GH}$ in lit/lit mice plasma (30) may inhibit the masculinizing effect of intermittent GH. Continuous infusion of $\mathrm{GH}$ to normal male rodents suppresses EGF binding (present results) and feminizes various other functions $(34,35)$. A continuous presence of $\mathrm{GH}$ in plasma of lit/lit mice could also explain why the female pattern of hepatic steroid metabolizing enzymes is not eliminated in female lit/lit mice (34) as in hypophysectomized female rats $(32,35)$.

A common mechanism of hormonal interaction involves regulation of receptor binding capacity. The present results demonstrate that GH induces EGF receptors, though the precise physiological significance of this finding remains unknown. While a growth-related process appears likely, few sustained growth-related effects have been observed after EGF treatment of adult animals. However, in addition to its other effects on the liver, EGF enhances hepatic DNA synthesis in adult rats and mice $(2,36)$, and there is recent evidence that the concentration of EGF receptors as well as of the ligand may influence cell proliferation under selected circumstances $(4,5)$.

It is well established that $\mathrm{GH}$ interacts with a growth factor other than EGF (i.e., IGF-I), and that GH-stimulated synthesis of IGF-I in various tissues mediates, at least in part, the stimulatory effect of GH on body growth (6-8). Although IGF-I and EGF interact under certain conditions in stimulating cell proliferation in vitro $(37,38)$, it remains unclear whether these growth factors interact in vivo, particularly in the liver, where there are relatively few IGF-I receptors in the adult rat (39). It is also currently unknown whether GH induces EGF receptors in tissues other than the liver.

Despite the above-mentioned unresolved questions, the present results raise the possibility that stimulation of EGF receptor levels and perhaps EGF sensitivity is of importance for the growth-promoting effect of GH. Thyroid hormone, which exerts an anabolic action on the liver of adult rodents (40), also induces hepatic EGF receptors (27). In addition, thyroid-stimulating hormone and estradiol increase EGF binding in the thyroid and the uterus, respectively, where these two hormones also stimulate cell proliferation $(41,42)$. Therefore, enhanced EGF binding may constitute a common step in a cellular growth pathway that can be initiated by different stimuli.

\section{Acknowledgments}

These studies were supported in part by National Institutes of Health grants DK-17947 and DK-30667 and by travel grants from the Swedish Medical Research Council and KabiVitrum AB.

\section{References}

1. Cohen, S., and J. M. Taylor. 1974. Epidermal growth factor: chemical and biological characterization. Recent Prog. Horm. Res. 30:533-550.

2. St. Hilaire, R. J., and A. L. Jones. 1982. Epidermal growth factor: its biologic and metabolic effects with emphasis on the hepatocyte. Hepatology (Baltimore). 2:601-613.

3. Carpenter, G. 1987. Receptors for epidermal growth factor and other polypeptide mitogens. Annu. Rev. Biochem. 56:881-914.

4. Velu, T. J., L. Beguinot, W. C. Wass, M. C. Willingham, G. T. Merlino, I. Pastan, and D. R. Lowry. 1987. Epidermal growth factordependent transformation by a human proto-oncogene. Science (Wash. DC). 238:1408-1410.

5. Di Fiore, P. P., J. H. Pierce, T. P. Fleming, R. Hazan, A. Ullrich, C. R. King, J. Schlessinger, and S. A. Aaronson. 1987. Overexpression of the human EGF receptor confers an EGF-dependent transformed phenotype to NIH 3T3 cells. Cell. 51:1063-1070.

6. Daughaday, W. H. 1981. Growth hormone and the somatomedins. In Endocrine Control of Growth. W. H. Daughaday, editor. Elsevier, New York. 1-24.

7. Isaksson, O. G. P., J.-O. Jansson, and I. A. M. Gause. 1982. Growth hormone stimulates longitudinal bone growth directly. Science (Wash. DC). 216:1237-1239.

8. D'Ercole, A. J., A. D. Stiles, and L. E. Underwood. 1984. Tissue concentration of somatomedin-C: further evidence for multiple sites of synthesis and paracrine and autocrine mechanisms of action. Proc. Natl. Acad. Sci. USA. 81:935-939.

9. Tannenbaum, G. S., and J. B. Martin. 1976. Evidence for an endogenous ultradian rhythm governing growth hormone secretion in the rat. Endocrinology. 98:562-570.

10. Jansson, J.-O., S. Eden, and O. Isaksson. 1985. Sexual dimorphism in the control of growth hormone secretion. Endocr. Rev. 6:128-150.

11. Jansson, J.-O., and L. A. Frohman. 1987. Differential effects of neonatal and adult androgen exposure on the growth hormone secretory pattern in male rats. Endocrinology. 1551-1557.

12. Sinha, Y. N., C. B. Salocks, M. A. Wickes, and W. P. Vanderlaan. 1977. Serum and pituitary concentrations of prolactin and growth hormone in mice during a twenty-four hour period. Endocrinology. 100:786-791.

13. Jansson, J.-O., K. Albertsson-Wikland, S. Eden, K.-G. Thorngren, and O. Isaksson. 1982. Effect of frequency of growth hormone administration on longitudinal bone growth and body weight in hypophysectomized rats. Acta. Physiol. Scand. 114:261-265. 
14. Clark, R. G., J.-O. Jansson, O. Isaksson, and I. C. A. F. Robinson. 1985. Intravenous growth hormone: growth responses to patterned infusions in hypophysectomized rats. J. Endocrinol. 104:53-61.

15. Gustafsson, J.-A., A. Mode, G. Norstedt, and P. Skett. 1983. Sex steroid induced changes in hepatic enzymes. Annu. Rev. Physiol. 45:51-60.

16. Benveniste, R., and S. A. Carson. 1985. Binding characteristics of epidermal growth factor receptors in male and female rat liver cell membrane preparations. Mol. Cell. Endocrinol. 41:147-151.

17. Alm, J., J. Lakshmanan, and D. A. Fisher. 1986. Sexual dimorphism and testosterone effects on liver epidermal growth factor receptors in mice. Acta Endocrinol. 113:140-144.

18. Eicher, E., and W. Beamer. 1976. Inherited ateliotic dwarfism in mice. J. Hered. 67:87-91.

19. Jansson, J.-O., T. R. Downs, W. G. Beamer, and L. A. Frohman. 1986. Receptor-associated resistance to growth hormone-releasing factor in dwarf "lit/lit" mice. Science (Wash. DC). 232:511-512.

20. Phillips, J. A., III, W. G. Beamer, and A. Bartke. 1982. Analysis of growth hormone genes in mice with genetic defects of growth hormone expression. J. Endocrinol. 92:405-407.

21. Chubb, C., and C. Nolan. 1985. Animal models of male infertility: mice bearing single-gene mutations that induce infertility. Endocrinology. 117:338-346.

22. Cuatrecasas, P. 1972. Affinity chromatography and purification of the insulin receptor of liver cell membranes. Proc. Natl. Acad. Sci. USA. 69:1277-1281.

23. Hock, R. A., and M. D. Hollenberg. 1980. Characterization of the receptor for epidermal growth factor-urogastrone in human placenta membranes. J. Biol. Chem. 255:10731-10736.

24. Lowry, O. H., N. J. Rosebrough, A. L. Farr, and R. J. Randall. 1951. Protein measurement with the Folin phenol reagent. J. Biol. Chem. 193:265-275.

25. Savage, C. R., Jr., T. Inagami, and S. Cohen. 1972. The primary structure of epidermal growth factor. J. Biol. Chem. 247:7612-7621.

26. Hoath, S. B., W. L. Pickens, J. C. Bucuvalas, and F. J. Suchy. 1987. Characterization of epidermal growth factors in the developing rat. Biochim. Biophys. Acta. 930:107-113.

27. Mukku, V. R. 1984. Regulation of epidermal growth factor receptor levels by thyroid hormone. J. Biol. Chem. 259:6543-6547.

28. Scatchard, G. 1947. The attractions of proteins for small molecules and ions. Ann. NY Acad. Sci. 51:660-672.

29. Woolf, C. M. 1968. Principles of Biometry. Van Nostrand, Princeton, NJ. 359 pp.
30. Herington, A. C., D. Harrison, and J. Graystone. 1983. Hepatic binding of human and bovine growth hormones and ovine prolactin in the dwarf "lit/lit" mouse. Endocrinology. 112:2032-2038.

31. Norstedt, G., and R. Palmiter. 1984. Secretory rhythm of growth hormone regulates sexual differentiation of mouse liver. Cell. 36:805-812.

32. Morgan, E. T., C. MacGeoch, and J.-A. Gustafsson. 1985. Hormonal and developmental regulation of expression of the hepatic microsomal steroid 16 alpha-hydroxylase cytochrome P-450 apoprotein in the rat. J. Biol. Chem. 260:11895-11898.

33. Husman, B., G. Norstedt, A. Mode, and J.-A. Gustafsson. 1985. The mode of growth hormone administration is of major importance for the excretion of the major male rat urinary proteins. Mol. Cell. Endocrinol. 40:205-210.

34. Noshiro, M., and M. Negishi. 1986. Pretranslational regulation of sex-dependent testosterone hydroxylases by growth hormone in mouse liver. J. Biol. Chem. 261:15923-15927.

35. Mode, A., J.-A. Gustafsson, J.-O. Jansson, S. Eden, and O. Isaksson. 1982. Association between plasma level of growth hormone and sex differentiation of hepatic steroid metabolism in the rat. Endocrinology. 111:1692-1697.

36. Richman, R. A., T. H. Claus, S. J. Pilkis, and D. L. Friedman. 1976. Hormonal stimulation of DNA synthesis in primary cultures of adult rat hepatocytes. Proc. Natl. Acad. Sci. USA. 73:3589-3593.

37. Balk, S. D., R. P. C. Shiu, M. M. LaFleur, and L. L. Young. 1982. Epidermal growth factor and insulin cause normal chicken heart mesenchymal cells to proliferate like their Rous sacroma virus-infected counterparts. Proc. Natl. Acad. Sci. USA. 79:1154-1157.

38. Russell, W. E., J. J. van Wyk, and W. J. Pledger. 1984. Inhibition of the mitogenic effects of plasma by a monoclonal antibody to somatomedin C. Proc. Natl. Acad. Sci. USA. 81:2389-2392.

39. Froesch, E. R., C. Schmid, J. Schwander; and J. Zapf. 1985. Actions of insulin-like growth factors. Annu. Rev. Physiol. 47:443-467.

40. Carr, F. E., S. Seelig, C. N. Mariash, H. L. Schwartz, and J. H. Oppenheimer. 1983. Starvation and hypothyroidism exert an overlapping influence on rat hepatic messenger RNA activity profiles. J. Clin. Invest. 72:154-163.

41. Westermark, K., B. Westermark, F. A. Karlsson, and L. E. Ericson. 1986. Location of epidermal growth factor receptors on porcine thyroid follicle cells and receptor regulation by thyrotropin. Endocrinology. 118:1040-1046.

42. Mukku, V. R., and G. M. Stancel. 1985. Regulation of epidermal growth factor receptor by estrogen. J. Biol. Chem. 260:9820-9824. 